\title{
Relationship between filler content and selected mechanical properties of six microhybrid composites
}

\section{Relação entre o conteúdo de carga e propriedades mecânicas de seis resinas compostas microhíbridas}

\begin{abstract}
Purpose: The purpose of this study was to evaluate the influence of filler weight content on selected mechanical properties of six microhybrid composite resins.

Methods: Compressive strength, elastic modulus, Vickers microhardness (VHN), and weight filler content were evaluated in the following dental composites: Admira (AD), Charisma (CH), InTen-S (IN), Tetric Ceram (TC), Point 4 (P4), and Z250 (Z2).

Results: Mean values for compressive strength (MPa) ranged from P4 76.60 to Z2 222.33. The elastic moduli (GPa) ranged from IN 2.56 to Z2 4.59. Microhardness VHN ranged from P4 50.53 to Z2 87.88. Filler weight content (Wt \%) ranged from IN 72.51 to TC 79.56. Significant differences were found between the composites (ANOVA/Tukey's, $P<0.05$ ).

Conclusion: Z2 had the highest compressive strength; Z2 and TC showed the highest elastic modulus, $\mathrm{VHN}$ and filler weight content. Weight filler content had a strong influence on mechanical properties $(0.78<R 2<0.98, P<0.01)$.
\end{abstract}

Key words: Composite resin; mechanical properties; dental materials

\section{Resumo}

Objetivo: O objetivo deste estudo foi avaliar a influência do conteudo de carga, em peso, de seis resinas compostas microhíbrida sobre determinadas propriedades mecânicas.

Metodologia: A resistência à compressão, módulo de elasticidade, microdureza Vickers (VHN) e conteúdo de carga de peso foram avaliados nas seguintes resinas compostas: Admira (AD), Charisma (CH), InTen-S (IN), Tetric Ceram (TC), Point 4 (P4) e Z250 (Z2).

Resultados: Os valores médios de resistência à compressão (MPa) variaram de P4 76,60 a Z2 222,33. Os módulos de elasticidade (GPa) variou de IN 2,56 a Z2 4,59. A microdureza VHN variou de P4 50,53 a Z2 87,88. O conteúdo de carga em peso (W+\%) variou de IN 72,51 a TC 79,56. Foram encontradas diferenças significativas entre as resinas compostas (ANOVA/Tukey's, $P<0,05)$.

Conclusão: A resina Z2 teve a maior resistência à compressão; Z2 e TC apresentaram maiores módulo de elasticidade, $\mathrm{VHN}$ e conteúdo de carga em peso. $\mathrm{O}$ conteúdo de carga em peso teve uma forte influência nas propriedades mecânicas avaliadas $(0,78<R 2<0,98$, $P<0,01)$.

Palavras-chave: Resina composta; propriedades mecânicas; materiais dentários

\author{
Eduardo Gonçalves Mota a \\ Adriano Weiss a \\ Ana Maria Spohr a \\ Hugo Mitsuo Silva Oshima a \\ Lígia Maria Nogarett de Carvalho a
}

a Pontifical Catholic University of Rio Grande do Sul, Porto Alegre, RS, Brazil
Correspondence:

Eduardo Gonçalves Mota

Pontifical Catholic University of Rio Grande do Sul

Av. Ipiranga 6681, Building 6

Porto Alegre, RS - Brasil

90619-900

E-mail: eduardo.mota@pucrs.br

Received: November 24, 2010

Accepted: February 6, 2011

Conflict of Interest Statement: The authors state that there are no financial and personal conflicts of interest that could have inappropriately influenced their work.

Copyright: (C) 2011 Mota et al.; licensee EDIPUCRS This is an Open Access article distributed under the terms of the Creative Commons AttributionNoncommercial-No Derivative Works 3.0 Unported License. 


\section{Introduction}

The application of composites in the dental clinic allows for conservatory and esthetic dentistry (1). The indications have been extended to direct anterior and posterior fillings, indirect inlays, onlays, veneers, crowns and partial fixed bridges.

In 1985, composite filling materials were classified using the average size of the inorganic filler (2), which became the standard for subsequent studies. Due to the many differences between materials in the same group, other methods of classification have been suggested based on various mechanical properties $(3,4)$.

Compressive strength, elastic modulus and flexural strength of these materials have been also evaluated (5-7) due to the direct influence of composition on mechanical behavior $(8,9)$. However, composites in the market are simply classified by inorganic filler average size, which suggests that resins in the same group have similar mechanical behavior. Therefore, this study tested whether universal microhybrid composites show similar mechanical properties (e.g., compressive strength, elastic modulus and Vickers microhardness) and similar influence of filler content on mechanical properties. The aims of this study were to compare and evaluate the compressive strength, elastic modulus and Vickers microhardness of six different composites and to determine the influence of weight filler content on the tested mechanical properties.

\section{Methods}

Six different microhybrid composites were used, and their composition and content as well as the shape of inorganic filler and the organic matrix are described in Table 1 .

\section{Compressive strength}

Twelve specimens for each group were manufactured using a PTFE mold with an inner diameter of $3 \mathrm{~mm}$ and a height of $6 \mathrm{~mm}(5,10,11)$. Three equal increments were inserted for each specimen and light-cured according to the manufacturers' instructions using the light-curing unit XL - 1500 (3M ESPE, St. Paul, MN, EUA). Light intensity $\left(450 \pm 20 \mathrm{~mW} / \mathrm{cm}^{2}\right)$ was checked every five exposures using a radiometer (Curing Radiometer Model 100, Demetron Co., Orange, CA, EUA). The specimens were stored in distilled water at $37^{\circ} \mathrm{C}$ for $24 \mathrm{~h}$ before testing.

Compressive strength was measured using a universal testing machine EMIC DL-2000 (Emic, São José dos Pinhais, PR, Brazil) at a $0.5 \mathrm{~mm} / \mathrm{min}$ cross-head speed. Records in Newtons $(\mathrm{N})$ were converted to megapascal $(\mathrm{MPa})$ by dividing the maximum failure load by the cross-sectional area. Data were statistically analyzed using an analysis of variance (ANOVA) and Tukey's test $(\alpha=0.05)$.

\section{Elastic Modulus}

Based on the compressive strength data, the elastic modulus was calculated by dividing the compressive strength by deformation (2), which was automatically obtained by Mtest software. Elastic modulus (GPa) data were analyzed using an ANOVA and Tukey's test $(\alpha=0.05)$.

\section{Vickers Microhardness}

Using a PTFE matrix, five specimens from each group were manufactured with a $4 \mathrm{~mm}$ and a $3 \mathrm{~mm}$ height. Two composite increments were inserted and light-cured. The specimens were embedded in cylinders of self-cured acrylic resin (Jet, Clássico, São Paulo, SP, Brazil), polished with 100-, 200- and 600-grit carbide silicon paper under water-cooling, and stored in individual containers with distilled water at $37^{\circ} \mathrm{C}$ for 24 hours. Microhardness (VHN) was measured two

Table 1. Evaluated materials (based on the information by manufacturers).

\begin{tabular}{|c|c|c|c|c|}
\hline Group & Material & Batch number & Organic Matrix & Filler Size $(\mu \mathrm{m})$ \\
\hline$A D$ & $\begin{array}{c}\text { Admira } \\
\text { (Voco, Cuxhaven, Germany) }\end{array}$ & 360192 & $\begin{array}{c}\text { Inorganic-organic siloxane polymer } \\
\text { BisGMA } \\
\text { HEMA } \\
\text { UDMA }\end{array}$ & 0.7 \\
\hline $\mathrm{CH}$ & $\begin{array}{c}\text { Charisma } \\
\text { (Heraeus-Kulzer, Hanau, Germany) }\end{array}$ & 080034 & BisGMA & 0.7 \\
\hline IN & $\begin{array}{c}\text { InTen-S } \\
\text { (Ivoclar Vivadent, Schaan, Liechtenstein) }\end{array}$ & E4 1790 & BisEMA & 0.7 \\
\hline P4 & $\begin{array}{c}\text { Point4 } \\
\text { (Kerr, Orange, CA, EUA) }\end{array}$ & 009328 & Dimetacrilates & 0.4 \\
\hline $\mathrm{TC}$ & $\begin{array}{c}\text { Tetric Ceram } \\
\text { (Ivoclar Vivadent, Schaan, Liechtenstein) }\end{array}$ & F53751 & $\begin{array}{l}\text { BisGMA } \\
\text { UDMA } \\
\text { TEGDMA }\end{array}$ & 0.7 \\
\hline $\mathrm{Z} 2$ & $\begin{array}{c}\text { Z250 } \\
\text { (3M ESPE, St. Paul, MN, EUA) }\end{array}$ & $1370 A 2$ & $\begin{array}{l}\text { BisGMA } \\
\text { BisEMA } \\
\text { UDMA }\end{array}$ & 0.6 \\
\hline
\end{tabular}


times per specimen using a load of $500 \mathrm{~g}$ for $15 \mathrm{~s}$ (Shimadzu HMV, Shimadzu, Kyoto, Japan). Data were statistically analyzed using ANOVA and Tukey's test $(\alpha=0.05)$.

\section{Thermogravimetric Analysis}

For each group, ten specimens of $20 \pm 10 \mathrm{mg}$ of composite were inserted in a platinum container and submitted to a heat rate of $20{ }^{\circ} \mathrm{C} / \mathrm{min}$ until $700{ }^{\circ} \mathrm{C}$ was reached (TGA 2050, TA Instruments, New Castle, DW, EUA). The temperature of organic matrix degradation and filler weight percent (Wt \%) were recorded. The amount of inorganic residues was established at the moment the sample's weight stabilized $(12,13)$. Inorganic content was determined by weighing the mass of the composite specimen before and after the elimination of the organic phase.

Data were compared using ANOVA and Tukey's test $(\alpha=0.05)$. The linear regression model was applied to verify the degree of influence of the inorganic phase on the mechanical properties.

\section{Results}

Table 2 displays the means and standard deviations of the experimental groups for compressive strength, elastic modulus, microhardness and filler weight content. Pairwise comparisons showed statistical differences among the tested composites $(P<0.05)$. Z2 had the highest compressive strength. Z2 and TC showed the highest elastic modulus, Vickers microhardness and filler weight content. The determination coefficients $\left(\mathrm{R}^{2}\right)$ of the inorganic filler content and mechanical properties are shown in Table 3 . Weight filler content strongly influenced all of the mechanical properties that were tested $\left(0.78<\mathrm{R}^{2}<0.98, P<0.01\right)$.

\section{Discussion}

Microhybrid composite resins are indicated to restore types I, II, III, IV and V. Therefore, it is expected that composites with the same classification will demonstrate similar mechanical behavior. However, a significant difference in the compressive strength among the composites from 222.33 MPa (Z2) to $76.60 \mathrm{MPa}$ (P4) was observed. These results disagree with other authors $(5,8)$, who found values between 242.3 and $324.7 \mathrm{MPa}$ and between 236.9 and 310.6 MPa (7) even when using materials with similar chemical compositions in the organic matrix (BisGMA, TEGDMA and UDMA) and filler content (66-85 Wt \%). Differences in sample size, crosshead speed, and storage medium are possible explanations for these different results.

The amount of filler weight directly increased the compressive strength $\left(0.78<\mathrm{R}^{2}<0.98\right)$. Previous studies $(8,14-17)$ have also reported differences in mechanical properties due to inorganic filler content. However, this influence was limited to composites with an inorganic content from 72.51 to $79.56 \mathrm{Wt} \%$ because composites with less than $60 \mathrm{Wt} \%$ or more than $80 \mathrm{Wt} \%$ show low mechanical strength compared to $75 \mathrm{Wt} \%$ materials (18).

According to their primary classification, the resinbased materials can be defined three-dimensionally by filler, organic matrix and bonding agent (2). Consequently, other features, such as diluents (10), degree of conversion (19), the curing method, composition, shape (20), and a medium-sized inorganic phase $(11,21)$, have been described in the literature as possible explanations for these differences. Therefore, multiple variables may influence the mechanical strength of composite resins.
Table 2. Means* and standard deviation of the experimental groups for compressive strength, elastic modulus, microhardness and filler weight content.

\begin{tabular}{ccccccccc}
\hline \multirow{2}{*}{ Group } & \multicolumn{2}{c}{$\begin{array}{c}\text { Compressive } \\
\text { strength (MPa) }\end{array}$} & \multicolumn{2}{c}{$\begin{array}{c}\text { Elastic modulus } \\
(\mathrm{GPa})\end{array}$} & \multicolumn{2}{c}{$\begin{array}{c}\text { Microhardness } \\
\text { (VHN) }\end{array}$} & \multicolumn{2}{c}{$\begin{array}{c}\text { Filler weight content } \\
\text { (W+\%) }\end{array}$} \\
\cline { 2 - 9 } & Mean & SD & Mean & SD & Mean & SD & Mean & SD \\
\hline AD & $119.21^{\mathrm{cd}}$ & 31.10 & $3.38^{\mathrm{b}}$ & 0.63 & $61.50^{\mathrm{c}}$ & 3.43 & $75.55^{\mathrm{b}}$ & 0.98 \\
$\mathrm{CH}$ & $169.98^{\mathrm{b}}$ & 59.43 & $3.42^{\mathrm{b}}$ & 0.7 & $66.92^{\mathrm{c}}$ & 2.46 & $76.33^{\mathrm{b}}$ & 0.77 \\
$\mathrm{IN}$ & $150.81^{\mathrm{bc}}$ & 34.10 & $2.56^{\mathrm{c}}$ & 0.63 & $78.36^{\mathrm{b}}$ & 6.7 & $72.51^{\mathrm{c}}$ & 1.06 \\
$\mathrm{P4}$ & $76.60^{\mathrm{d}}$ & 22.11 & $3.07^{\mathrm{bc}}$ & 0.53 & $50.53^{\mathrm{d}}$ & 2.27 & $75.61^{\mathrm{b}}$ & 0.56 \\
$\mathrm{TC}$ & $155.11^{\mathrm{bc}}$ & 41.96 & $4.35^{\mathrm{a}}$ & 0.81 & $80.61^{\mathrm{ab}}$ & 8.39 & $79.56^{\mathrm{a}}$ & 0.86 \\
$\mathrm{Z2}$ & $222.33^{\mathrm{a}}$ & 44.78 & $4.59^{\mathrm{a}}$ & 0.37 & $87.88^{\mathrm{a}}$ & 8.95 & $78.72^{\mathrm{a}}$ & 1.1 \\
\hline
\end{tabular}

* Means followed by different letters are statistically different at $\alpha=0.05$.

\begin{tabular}{ccccc}
\hline Group & $\begin{array}{c}\text { Mean filler weight } \\
\text { content }\left(\mathrm{W}_{+} \%\right)\end{array}$ & $\begin{array}{c}\text { Compressive } \\
\text { strength }\end{array}$ & Elastic modulus & Microhardness \\
\hline $\mathrm{AD}$ & 75.55 & $\mathrm{R}^{2}=0.90$ & $\mathrm{R}^{2}=0.98$ & $\mathrm{R}^{2}=0.86$ \\
$\mathrm{CH}$ & 76.33 & $\mathrm{R}^{2}=0.92$ & $\mathrm{R}^{2}=0.96$ & $\mathrm{R}^{2}=0.92$ \\
$\mathrm{IN}$ & 72.51 & $\mathrm{R}^{2}=0.93$ & $\mathrm{R}^{2}=0.81$ & $\mathrm{R}^{2}=0.91$ \\
$\mathrm{P} 4$ & 75.61 & $\mathrm{R}^{2}=0.94$ & $\mathrm{R}^{2}=0.78$ & $\mathrm{R}^{2}=0.78$ \\
$\mathrm{TC}$ & 79.56 & $\mathrm{R}^{2}=0.87$ & $\mathrm{R}^{2}=0.92$ & $\mathrm{R}^{2}=0.89$ \\
$\mathrm{Z2}$ & 78.73 & $\mathrm{R}^{2}=0.91$ & $\mathrm{R}^{2}=0.90$ & $\mathrm{R}^{2}=0.88$ \\
\hline
\end{tabular}

Table 3. Determination coefficient $\left(R^{2}\right)$ of the degree of influence of the inorganic phase for the evaluated mechanical properties. 
The Ormocer technology, which is an organically modified ceramic that was introduced as Admira, promotes a higher bonding of the resinous matrix to an organicinorganic filler according to the manufacturer's information. This material showed a compressive strength $(119.21 \mathrm{MPa})$ that was statistically lower than other composites with the same filler average size $(0.7 \mu \mathrm{m})$ but similar to Point $4(76.60 \mathrm{MPa})$. An improvement in filler-matrix bonding does not necessarily result in a higher mechanical strength of high-filled composites $(22,23)$.

The variability of monomers that are incorporated into the resin offers another explanation for the high positive correlation between compressive strength and weight filler content (24). Different amounts of filler content show similar flexural strength, depending on the volume of UEDMA, BisGMA and TEGDMA (25). Resins that contain $70 \mathrm{~mol} \%$ of UDMA and $30 \mathrm{~mol} \%$ of TEGDMA without BisGMA show excellent mechanical strength. Composites with a $50 \%$ BisGMA and $50 \%$ TEGDMA without UDMA show high elastic moduli (6). TEGDMA monomer improves the degree of conversion and greatly increases polymerization shrinkage and flow. Higher molecular weight monomers, such as UDMA and BisEMA, allow thicker increments and a decrease in shrinkage and degree of conversion.

The average size of the inorganic phase suggests an influence on strength. Point 4 , which has a $0.4-\mu \mathrm{m}$ filler size, showed a statistically lower compressive strength average of $76.60 \mathrm{MPa}$. According to the manufacturer, this material behaves similarly to other microhybrid composites. However, composites with a 0.6 - to $0.7-\mu \mathrm{m}$ filler size showed statistically higher averages $(\mathrm{Z} 2, \mathrm{CH}, \mathrm{TC}$ and IN). The influence of filler shape has been described (25). This composite showed the highest compressive strength (222.33 MPa). InTen-S and Tetric Ceram have a mix of spherical and irregular shape fillers. These composites showed statistically lower compressive strength (150.81 and $155.11 \mathrm{MPa}$, respectively) than Z250, but they were statistically equal. Therefore, the composite resin with monomers with high molecular weight (BisEMA), which are associated with spherical shape fillers, had higher compressive strength than composites with irregular shape fillers and diluent in the matrix.

Elastic modulus was also evaluated; it represents a mechanical behavior that is obtained from the tensile-strain graphic. The elastic modulus is inversely proportional to the capability of a material to deform. Our results ranged from 2.56 to $4.59 \mathrm{GPa}$, which differs from other studies that have reported values from 8 to $11.1 \mathrm{GPa}(6)$ and 12 to $15 \mathrm{GPa}$ (13). The variety of methods of calculating the elastic modulus explains the disagreement. The elastic modulus can be obtained from three point flexural strength or toughness strength in which tensile distribution differs from the compressive test (6).

The strong positive influence of filler content on the elastic modulus $\left(0.81<\mathrm{R}^{2}<0.98\right)$ agrees with the uniform improvement of the elastic modulus and hardness with filler content. The differences can be explained by the organic phase differences because the elastic modulus decreases with the amount of UEDMA. By varying the concentration of UEDMA, BisGMA and TEGDMA that is associated with the filler, it is possible to obtain composites with the opposite mechanical behavior (6). Composite resins with higher amounts of TEGDMA show a strong degree of conversion and higher mechanical properties (19).

Our results of microhardness ranged from $50.53 \mathrm{VHN}$ (P4) to $87.88 \mathrm{VHN}(\mathrm{Z} 2)$. Rounded fillers allow for a higher amount of inorganic phase (13) and, consequently, the higher hardness that was observed with Z250 (78.73 Wt \%, $87.88 \mathrm{VHN})$. Tetric Ceram (79.56 Wt \%, 80.61 VHN) has a mixture of irregular and rounded particles, and it demonstrated numerically a VHN with no statistically significant difference. Composites with irregular fillers showed intermediate hardness (Charisma, 66.92 VHN, and Admira, $61.50 \mathrm{VHN}$ ).

The strong influence $(0.78<\mathrm{R} 2<0.98)$ of weight content on microhardness has also been reported previously (24). Hardness increases uniformly with filler amount, and there is a direct correlation with inorganic phase and VHN (12).

Thermogravimetric analysis is a method for the determination of filler content based on the mass weighing of a composite before and after the elimination of the organic phase by heating. Results ranged from 72.51 to $79.56 \mathrm{Wt} \%$, which are in agreement with a previous study that observed an average of $73(20)$.

The differences that we observed are related to the maximum filler amount in a composite resin with higher molecular weight monomers, such as BisGMA, UDMA and BisEMA. Tetric Ceram (79.56 Wt \%) and Z250 (78.73 Wt \%) confirm this hypothesis.

Finally, despite the limitations of an in vitro study, it is possible to observe a large variability in mechanical properties among microhybrid composites. Other mechanical properties, such as degree of conversion, flexural strength, and flexural modulus, should be evaluated to improve the understanding of composite mechanical behavior. art and future perspectives. Quintessence Int 2002;33:213-24.

2. Lutz F, Phillips RW. A classification and evaluation of composite resin systems. J Prosthet Dent 1985;50:480-8

3. Hosoda H, Yamada T, Inokoshi S. SEM and elemental analysis of composite resins. J Prosthet Dent 1990;64:669-76. 
4. Lang BR, Jaarda M, Wang RF. Filler particle size and composite resin classification systems. J Oral Rehab 1998; 19:569-84.

5. Brosh T, Ganor Y, Belov I, Pilo R. Analysis of strength properties of light-cured resin composites. Dent Mater 1999;15:174-9.

6. Asmussen E, Peutzfeldt A. Influence of UEDMA, BisGMA and TEGDMA on selected mechanical properties of experimental resin composites. Dent Mater 1998;14:51-6.

7. Cobb DS, MacGregor KM, Vargas MA, Denehey GE. The physical properties of packable and conventional posterior resin-based composites: a comparison. J Am Dent Assoc $2000 ; 131: 1610-5$.

8. Chung KH, Greener, EH. Correlation between degree of conversion, filler concentration and mechanical properties of posterior composite resins. J Oral Rehab 1990;17: 487-94.

9. Say EC, Civelek A, Nobecourt A, Ersoy M, Guleryuz C. Wear and microhardness of different resin composite materials. Oper Dent 2003;28:628-34.

10. Krishnan VK, Manjusha K, Yamuna V. Effect of diluent upon the properties of a visiblelight-cured dental composite. J Mater Sci Mater Med 1997;8:703-6.

11. Krishnan VK, Yamuna V. Effect of initiator concentration, exposure time and particle size of the filler upon the mechanical properties of a light-curing radiopaque dental composite. J Oral Rehab 1998;25:747-51.

12. Neves AD, Discacciati JAC, Oréfice RL, Jansen WC. Correlation between degree of conversion, microhardness and inorganic content in composites. Braz Oral Res 2002; 6:349-54.

13. Kim KH, Ong JL, Okuno O. The effect of filler loading and morphology on the mechanical properties of contemporary composites. J Prosthet Dent 2002;87:642-9.

14. Raptis CN, Fan PL, Powers JM. Properties of microfilled and visible light-cured composite resins. J Am Dental Assoc 1979;99:631-3.

15. Li Y, Swartz ML, Phillips RW, Moore BK, Roberts TA. Effect of filler content and size on properties of composites. J Dent Res 1985;64:1396-401.

16. Chung $\mathrm{KH}$. The relationship between composition and properties of posterior resin composites. J Dent Res 1990;69:852-6.

17. Willems G, Lamberchts P, Braem M, Celis JP, Vanherle G. A classification of dental composites according to their morphological and mechanical characteristics. Dent Mater 1992;8:310-9.

18. Htang A, Ohsawa M, Matsumoto $H$. Fatigue resistance of composite restorations: effect of filler content. Dent Mater 1995;1 1:7-13.

19. Ferracane JL, Greener EH. The effect of resin formulation on the degree of conversion and mechanical properties of dental restorative resins. J Biomed Mater Res 1986;20: $121-31$.

20. Kim KH, Okuno O. Microfracture behavior of composite resins containing irregular-shaped fillers. J Oral Rehab 2002;29:1 153-9.

21. Mitra SB, Wu D, Holmes B. An application of nanotechnology in advanced dental materials. J Am Dental Assoc 2003;134:1387-90.

22. Venhoven BA, de Gee AJ, Werener A, Davidson C L. Influence of filler parameters on the mechanical coherence of dental restorative resin composites. Biomaterials 1996;17: 735-40.

23. Debnath S, Ranade R, Wunder SL, McCool J, Boberick K, Baran G. Interface effects on mechanical properties of particle-reinforced composites. Dent Mater 2004;20:677-86.

24. Halvorson RH, Erickson RL, Davidson CL. The effect of filler and silane content on conversion of resin-based composite. Dent Mater 2003;19:327-33.

25. Abado LG, dos Santos Cruz CA, Fonseca RG, Vaz LG. The volumetric fraction of inorganic particles and the flexural strength of composites for posterior teeth. J Dent 2003;31: 353-59. 